\title{
Positive Aesthetics: claims and problems ${ }^{1}$
}

\author{
María José Alcaraz León \\ Universidad de Murcia \\ Facultad de Filosofía \\ mariajo@um.es
}

\begin{abstract}
In this paper I present an overview of the doctrine known as Positive Aesthetics regarding aesthetic judgements about nature. According to this view, all pristine nature is always beautiful and, generally, although not necessarily, human intervention tends to introduce ugliness in nature. One of the strong practical motivations behind this claim is an attempt to ground our reasons to preserve natural environments in aesthetic reasons.

Positive Aesthetics has been defended within contrary approaches to nature appreciation such as the cognitivists and the anti-cognitivist. Recently, the possibility of real ugliness in nature has been defended; at the same time, it is argued that the presence of ugly items in nature does not lead necessarily to the idea that they are not aesthetically valuable. Hence, natural ugliness can be a reason to preserve nature. In this sense, the denial of the Positive Aesthetics claim is shown to be compatible with the appeal to aesthetic negative qualities as a source of reasons for preserving natural environments.
\end{abstract}

Key words: Positive Aesthetics, cognitivism and anti-cognitivism about aesthetic judgments of natural items, nature's preservation, real ugliness.

\section{Resumen. Estética Positiva. Tesis y problemas}

En este texto presento un panorama de la doctrina conocida como «Estética Positiva» en relación a los juicios estéticos sobre la naturaleza. Según esta concepción, toda la naturaleza prístina es bella; además se considera que, en general, aunque no de manera necesaria, la intervención humana tiende a introducir fealdad en la naturaleza. Una de las motivaciones prácticas tras esta afirmación es la de tratar de fundamentar nuestras razones para preservar el medio ambiente en razones estéticas.

La doctrina de la Estética Positiva ha sido defendida por teorías de la apreciación estética tan diferentes como las cognitivistas y las anti-cognitivistas. Recientemente, se ha tratado de defender la posibilidad de que exista fealdad real en la naturaleza; al mismo tiempo, se ha argumentado que la presencia de elementos feos en la naturaleza no implica necesariamen-

1. This work has been possible thanks to the finantial support of the research Project «Emoción y Valor Moral en el Arte» (FFI2008-00750/FISO) and "Emoción y Valor Moral en el Arte: teoría y praxis artísticas» 08694/PHCS/08 financiado por la Fundación SénecaAgencia de Ciencia y Tecnología de la Región de Murcia en el marco del II PCTRM 2007-2010. 
te que esos objetos carezcan de valor estético. De hecho, de acuerdo con esta aproximación al problema, la fealdad natural puede ser una razón para preservar la naturaleza. En este sentido, la negación de la tesis de la Estética Positiva es compatible con la apelación a cualidades estéticas negativas como una fuente de razones para preservar los espacios naturales.

Palabras clave: Estética Positiva, cognitivismo y anti-cognitivismo sobre los juicios estéticos de los objetos naturales, preservación de la naturaleza, fealdad real.

\section{Summary}

Positive Aesthetics: Some defenders

The cognitive approach
Non-cognitivist defence of Positive Aesthetics Some alternatives to Positive Aesthetics

The view that all nature untouched by humans is always beautiful, known as "Positive Aesthetics», has its roots in the XIXth Century American literature. Writers such as Ralph W. Emerson and Henry D. Thoreau began to portray nature as a locus for a particular non-instrumental experience, which can only be narrowly described as aesthetic. The aesthetic contemplation of pristine nature stimulated a sort of metaphysical reflection about the place of human beings within nature. Both the perceptual engagement in this experience and the object that triggered it were considered as something valuable in themselves. This idea served also the preservationist purposes that have become widespread nowadays: If nature is always beautiful we have a prima facie reason to not to alter it or damage it.

The view, later embraced by some naturalists lacked, however, the necessary philosophical back up for it to be seriously taken. Despite the fact that it found support among those who reflected upon nature and who exhibited an interest in it that went beyond instrumental considerations, its philosophical weaknesses were noticeable enough for it not to be a strong position. First of all, it encountered sheer evidence in the many examples of natural beings and environments that can hardly be considered as beautiful. Secondly, it seemed that part of the reasons alleged in favour of the main claim were motivations rather than justifications of it. It is out of a preservationist desire that natural beauty is over-generalized rather than the other way round.

However, and partly linked to a revitalization of the broader area of the Aesthetics of Nature in the middle sixties, the view gained some new support from defenders who embraced a more serious philosophical stance. However disputable, the claim that pristine nature is always beautiful found a stronger defence, which has grown and improved in the last decades.

Here I would like to present some of the main arguments in favour of this view as well as some possible criticism against it. Finally, I would like to address a recent approach, which holds the aesthetic value of nature is compatible with the acknowledgment that it can at times be ugly. If this is so, the preservationist can still make a claim even if the thesis that all nature is beautiful does not stand. 


\section{Positive Aesthetics: Some defenders}

Although the view is clear in its target, the reasons that have been offered for its defence range over a rather varied spectrum. Let's start with what they all have in common.

Any defender of the Positive Aesthetic claim needs to establish, even before arguing for its characteristic claim, that nature, despite its lack of intentionality, can be regarded from an aesthetic point of view. Together with this claim they normally hold that however the aesthetic experience of nature is characterized, it should always be such that takes nature as nature, and not as something else. This might seem obvious to some; but given a certain view of aesthetic value it may be less easy to establish. According to this view, for an object to possess aesthetic value it has to have been done intentionally so that its form - upon which its aesthetic value dependscan be specified in a certain way. Where no intention has moulded or shaped anything in a particular object, it becomes difficult to tell what exactly to look at or what might be of aesthetic relevance. Thus, a defender of positive aesthetics needs, in the first place, to make room for an aesthetic experience of non-intentional objects, and, secondly, to show that the way this is implemented does not merely results from the projection of artistic standards upon our experience of nature.

The first point easily obtains within a broader view of aesthetic interest, such as Kant's who did not circumscribed aesthetic experience to art at all. The second is slightly difficult for, even if aesthetic judgements of nature may be consciously made in order to avoid that sort of projection, it is much more difficult to dispel all sorts of influences when it comes to judge a particular object. Our aesthetic approach to nature cannot be but partly constituted by our artistic sensibility. Specially where the categories used to describe these experiences belong both to art experience and to the aesthetic experience of nature it becomes difficult to draw a sharp line between the two. This might be so, however, in such a way that the charge of projectionism is misplaced or overrated. That some categories may be applied across different realms does not involve our aesthetic appreciation of nature is just the result of projecting artistic terms onto it. We may have a view about our aesthetic concepts such that they become richer as we apply them to several realms where the notion of aesthetic experience may be appropriate.

Once the legitimacy of an aesthetic approach to nature is established differences began to arise among those who defend the view that pristine nature is always beautiful. We will group these differences according to the sort of reasons considered as valid for this claim. 


\section{The cognitive approach}

One of the seemingly more persuasive arguments for the Positive Aesthetic view is forged within the cognitive approach defended, among others, by Allen Carlson ${ }^{2}$.

Carlson has defended the view that a proper aesthetic approach to nature should satisfy a cognitive requirement. As well as we need to take into account the category under which a particular artwork belongs to to properly grasp its aesthetic value, we need to correctly categorize the natural object aesthetically contemplated if we are to capture its aesthetic qualities rightly. According to Carlson, the relevant categories when it comes to the aesthetic appreciation of nature are those provided by science. Only when we rightly place an object under its scientific outlook can we aspire to grasp its aesthetic value. As he puts it: «in the case of the natural environment the relevant knowledge is the common sense/scientific knowledge that we have discovered about the environment in question. This knowledge gives us the appropriate foci of aesthetic significance and the appropriate boundaries of the setting so that our experience becomes one of aesthetic appreciation" ${ }^{3}$

This cognitive claim does not directly imply that all nature is beautiful but it seems to fit a familiar case, which renders the view more persuasive. In particular, it seems to fit the case in which our aesthetic evaluation of a particular plant or animal becomes positive once we know more about it from a scientific point of view. If we generalize this case, a defender of the Positive Aesthetic view could say that when we find ugliness in nature it is normally due to the fact that we have misplaced the item; and, consequently, a proper categorization will render beautiful what seemed ugly in the first place. Very often, we find ourselves finding beautiful animals, which at first were judged as ugly; normally, this change goes hand in hand with a better understanding of the animal we are judging.

Nevertheless, and despite the persuasive tone of this line, cognitivism is not enough to grant all nature is beautiful. First, there might be cases where a correct categorization does not make ugliness to disappear. It does not matter how much knowledge we have about them, they do not just become prettier. Holding the opposite is just a stubborn way to confuse cognitive appreciation with aesthetic one ${ }^{4}$. Secondly, there might be cases where it is precisely the adequate knowledge that will render the item ugly. We have also typically encounter pic-

2. Carlson, Allen (1984). «Nature and Positive Aesthetics». Environmental Ethics, 6, p. 5-34.

3. Carlson, Allen (2004). "Appreciation and the Natural Environment». In: CARLSON, Allen; BERLEANT, Arnold (eds.). The Aesthetics of Natural Environments. Toronto: Broadview Press, p. 71-72.

4. Malcolm Budd has offered a version of this criticism in his BudD, M. (2002). The Aesthetic Appreciation of Nature. Essays on the Aesthetics of Nature. Oxford: Clarendon Press. In fact, he has defended that there are no substancial reasons to prefer a particular conceptual framework rather than another —or none- at all when it comes to aesthetically appreciate nature. 
tures we are not sure what they are about and that may be judged as depicting something beautiful but that become ugly once we know what they really represent. Thus, an image of a scar or a wound may sometimes look beautiful if we do not know the picture's content; but if we come to know what it is represented we may judge it as repulsive or ugly. Finally, there are cases where the aesthetic judgement seems correct despite the fact that we possess wrong information about the item judged. A typical example to illustrate this case is when we judge a whale to be impressive but we believe it to be a fish ${ }^{5}$. It is very likely that we will judge it similarly had we known it is a mammal, so if there are cases where a category mistake still produces right aesthetic judgements, aesthetic cognitivism seems unnecessary. These problems show cognitivism is not necessary, nor sufficient to grant the Positive Aesthetics' main claim.

A way to amend the cognitivist view is to preserve the intuition that a proper evaluation of a natural item requires the correct categorization but promoting a wider understanding of the category framework that has to be taken into consideration. Instead of exclusively accepting scientific theories as the right category framework, one could argue categories other than scientific could play the fixing role. Along these lines we can place efforts such as Yuriko Saito ${ }^{6}$ or Noël Carroll's ${ }^{7}$. According to Saito's view, it is too restrictive to assume that only scientific categories can properly aesthetically frame the item judged. Our very relationship with nature goes beyond any scientific approach and, therefore, other category sets can play a legitimate role in fixing what aspects of the item are to be considered in order to determine the aesthetic focus. She particularly points out frameworks deriving from mythological perspectives and folklore. The important point, in her view, is to keep in mind that we should treat nature as what it is, i.e., not art. But once this requirement is meet, several ways of categorizing nature can take part of our aesthetic appreciation. Nevertheless, it is still doubtful that beauty will always result from this enlarged framework. Against this hope we may pose a similar worry to the one offered against Carlson. Hence, no matter how acutely or richly we describe a natural item there is always the possibility that its ugliness do not just disappear.

Another attempt to rescue the cognitive approach has been provided by Glenn Parsons ${ }^{8}$. He also believes right appreciation requires correct description but he thinks this cannot by itself provide the necessary support to the Positive Aesthetic claim. What is needed, in his view, is an amendment of the structure of cognitivism. He thinks one of the criteria to decide among several scientific theories has to be precisely an aesthetic one. He notices we usually hold a naif

5. This example has been offered by Noël Carroll in his Carroll, N. (2004). «On Being Moved by Nature: Between Religious and Natural History». In: CARLSON, Allen; BERLEANT, Arnold (eds.) Op. cit., p. 89-107.

6. SAITO, Yuriko (2004). "Appreciating Nature on its own terms». In: CARLSON, Allen; BERLEANT, Arnold (eds.). Op. cit., p. 141-155.

7. See reference on note 4 .

8. PARSONS, Glenn (2002). "Nature Appreciation, Science, and Positive Aesthetics». British Journal of Aesthetics, vol. 42, n. 3, July, p. 279-295. 


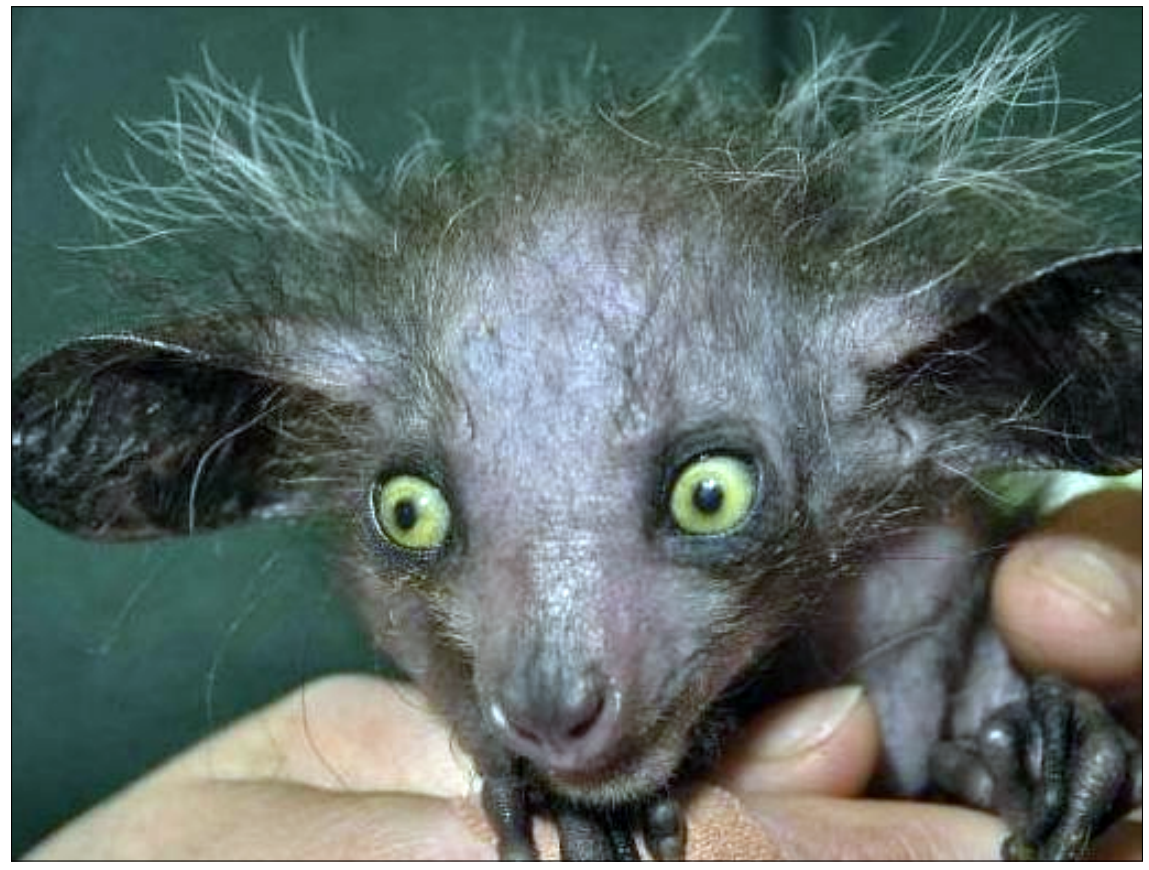

scientific view that may conflict with a more sophisticated understanding of the items we judged. When this is the case, we should choose the category that maximizes the aesthetic value of what we judge. This will grant that in those cases where some of our categories seem to support a judgement of ugliness but others present it under a more benevolent light, we choose the later given that they maximize the overall aesthetic worth of the particular item. A prima facie worry with this view is that it seems to be badly circular. If the Positive Aesthetics view is to find some support in our judging practices, it seems odd to recommend we always choose those categories that will maximize the aesthetic value. If two categories generate conflicting aesthetic experiences, it seems arbitrary that we choose one over the other just in virtue of the maximization of aesthetic value, especially when that is precisely the point at stake.

Frank Sibley ${ }^{9}$ has also approached the issue of aesthetic judgements of nature and, although he has not endorsed cognitivism properly speaking he has offered some support to the idea that natural items cannot be ugly unless i) they are seen under a given category and ii) they are a deformed token within that category. For him, species as such cannot be said ugly. Only members of a species can be so, if they are deformed tokens of it. It follows

9. Sibley, Frank (2000). «Some Notes on Ugliness». In: Sibley, F.; Benson, J.; Roxbee CoX, J.; Redfern, H. (eds.). Approach to Aesthetics. Oxford: Clarendon Press. 


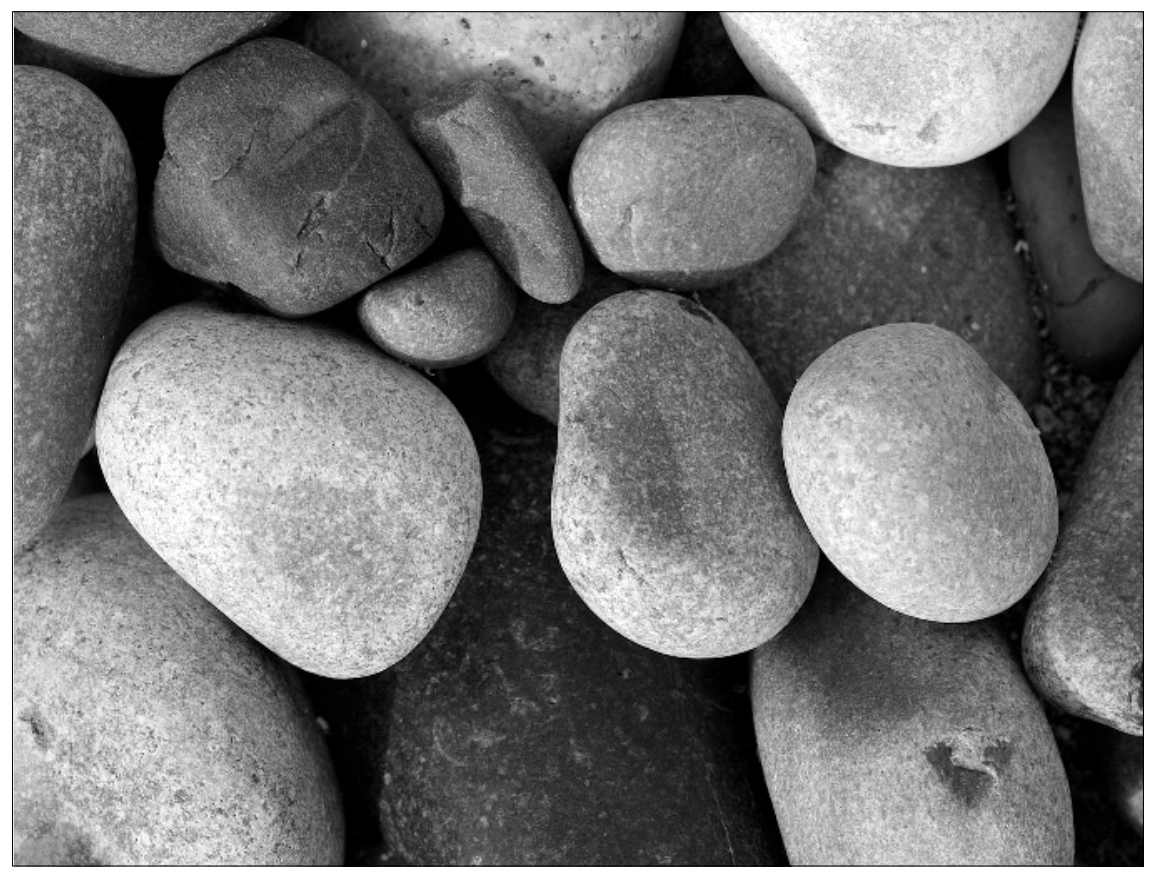

from his view that categories where it does not make sense to talk of deformity cannot have or contain ugly tokens either. Thus, Sibley points out that pebbles or clouds, for example, can never be ugly. Although Sibley is not directly endorsing the view that proper aesthetic appreciation requires correct categorization, he assumes ugliness is uniquely caused by deformity and that there cannot be predicative uses of ugliness. These two claims may be challenged. The first is easily defeated by cases where the judgement of ugliness is not based upon a perceived deformity but rather upon some other feature. The second is similarly challenged once we come to see some species are, by themselves, ugly. Thus, a typical example appealed to in order to challenge Sibley's point is the aye-aye from Madagascar or the star-nose mole.

In favour of Sibley, however, it can be said that he seems right in pointing that some things, like pebbles or clouds, can be hardly found ugly; whether this confirms his claim that natural ugliness is always a matter of deformity seems still disputable.

\section{Non-cognitivist defence of Positive Aesthetics}

It seems that despite the effort to bring nature home by making it more familiar through knowledge or categorizations, there are still stubborn cases of ugliness that render these efforts useless. 


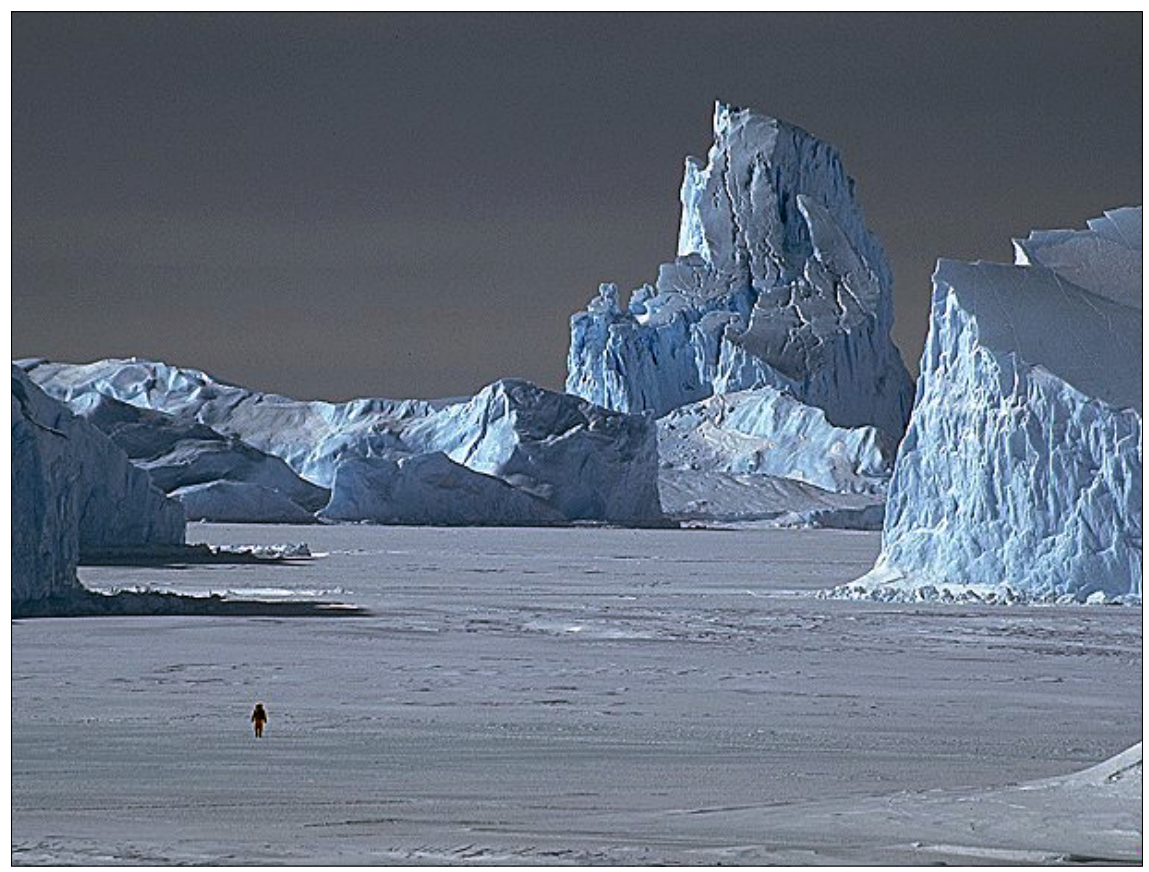

In fact some authors has seen them not only as unfruitful but also as misguided. Approaching nature as nature should involve precisely the abandon of any attempt to categorize it. Nature is essentially unknowable. In spite of all the categories we choose in order to make it more comprehensible, we will never be able to grasp it. Besides, those attempts cannot be anything but projections of our particular human perspective; and projections are not trustworthy.

Stan Godlovitch ${ }^{10}$ has strongly defended this view and has promoted an approach to nature, which barely allows enjoying two sorts of feelings: awe and admiration. According to his view, the main principle that should be respected is that of treating nature as nature and not as something else or as art. He then defends the view that the most comprehensive attitude towards nature should take the form of an a-centric perspective - one in which our own position as human beings is of no significance. Only within an a-centric perspective can we take equally into account every natural aspect. Discrimination or relativization are not worries to be had if we follow this principle

10. Godlovitch, Stan (1984). «Nature and Positive Aesthetics». Environmental Ethics, 6, p. 5-34. Godlovitch, S. (1998). "Evaluating Nature Aesthetically». Journal of Aesthetics and Art Criticism, 56, p. 113-125. GodloviTCH, S. (1998) «Valuing Nature and the Autonomy of Natural Aesthetics». British Journal of Aesthetics, 38, p. 180-197. 
for it precisely erases any point of view from which one can start ordering what it is intrinsically lacking order. Nothing more remote to cognitivism can be stated and, in fact, Godlovitch offers his own view as an antagonist to the one offered above.

Among the several problems that can be posed against this view, it is remarkable its naif depiction of the allegedly exclusively possible respectful relationship towards nature as one where human presence is almost erased. If aesthetic appreciation is typically spreading from human faculties, it makes little sense to elaborate a notion of aesthetic stance that builds itself independently of sensitive beings. It is a trivial truth that had we had a different sensibility our aesthetic experience would have been different. This, however, is far from showing there is a possible non-relative aesthetics as opposed to a human-relative one. Our respect towards nature may go beyond our aesthetic outlook, but it seems rather unavoidable to make reference to human sensibility if we are to talk about aesthetics at all. Something positive may be kept from this view, though. In remarking the possibility of a different aesthetic sensibility one can construe an argument for preservation that goes beyond what we actually value aesthetically. Maybe, given our sensibilities there are aspects of nature we are deaf or blind to. However, these aspects may become aesthetically relevant for us in the future or for other sensitive beings with a different aesthetic outlook.

Another worry with this view is that it barely counts as a defence of the Positive Aesthetic view for it does not establish all nature is beautiful. Rather it presents it such that our aesthetic terms will fall sort of grasping it. What seems to follow from Godlovitch's approach is that the best attitude we may aspire to is one of silent respect and awe.

\section{Some alternatives to Positive Aesthetics}

As I have pointed out above one of the motivations for the Positive Aesthetic claim is the preservation of nature. In this sense, it was thought that nature's beauty could provide a good reason not to destroy it. However, it has recently been argued ${ }^{11}$ that we may keep our preservational motivations while acknowledging nature is sometimes ugly. In short, ugliness can be an aesthetic value worth preserving and its recognition will make us more accurate both philosophical and empirically speaking. Emily Brady has put this view forward. She has discussed the validity of the Positive Aesthetics claim as well as proposed a positive view of natural ugliness.

As she has, I think rightly, pointed out, most of the arguments in favour of the Positive Aesthetic view fails. This, together with wide empirical evidence, speaks in favour of acknowledging natural ugliness is as widespread as natural beauty. In fact, the denial of natural ugliness seems to spread from a mystification of nature, to say the least. Once this is admitted, a defender of a preservationist policy may find herself in a odd situation if she hoped to ground

11. Brady, Emily (2010). «Ugliness and Nature», published in this same issue. 


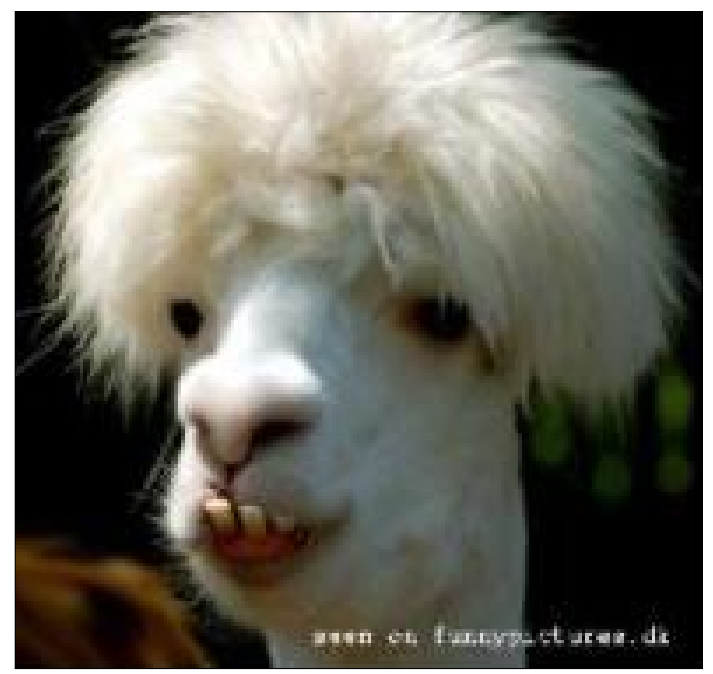

it upon aesthetics concerns. Given that ugliness is a negative aesthetic value, we seem to be deprived of an aesthetic reason to preserve those items that we judge to be ugly. How can one then reconcile a preservationist policy with the recognition of ugliness in nature?

As Brady has pointed out, no strategy that turns ugliness into some sort of difficult beauty will work. The point is not to turn ugliness into beauty but to recognize that natural ugliness may be valuable for us. Certainly it seems more difficult to show something with negative - aesthetic or of any other kind - value may be valuable in virtue of it. Normally, cases in which something becomes valued due to its negative value are cases in which the negative value is considered as unavoidable in order to get a higher goal. Thus pain may be necessary in order to achieve a certain state but that does not mean we value pain as such, only instrumentally speaking.

However, it seems this is not a good strategy either. We aim at showing not that ugliness may be sometimes the price paid to get a more rewarding aesthetic experience, but that it is worth it in itself. Brady's strategy has been to draw a parallel between tragedy and nature. As well as tragedy is valuable precisely in virtue of arousing negative feelings in the audience, ugliness in nature may be equally justifiably valuable. However, does the analogy work? It seems more or less accepted that the cognitive and moral benefit of tragedy is intimately linked to the sort of negative experience it arouses in the audience. In fact, it is claimed it is intrinsic to the cognitive gain that it is achieved through that particular experience. Now, while it seems obvious that in the case of tragedy the negative experience finds a sort of internal cognitive justification and that, hence, its value cannot be detached from it, it seems more difficult to describe the negative value of natural ugliness in these terms. For what is 
the cognitive payoff — or any other sort of gain-that natural ugliness may offer to us in order to justify its value? Can we find a counterpart in the case of natural ugliness for the painful experience that we typically value in tragedy?

A possible answer could be that we will not enjoy natural beauty as much if it was not for the alternative presence of natural ugliness. Maybe, when it comes to aesthetics, contrasts are more important than it may appear. Thus, a natural world with no ugliness whatsoever could be overall considered as less aesthetically interesting as one where we find instances of both values.

Another response can be articulated by appealing to a complex understanding of our aesthetic responses to nature. This would require, in turn, a complex view about aesthetic experience in general and the extent to which they not only manifest our sensibility but also features of our relationship to the world as a whole. According to this view aesthetic engagement is not simply a matter of responding with pleasure or displeasure to patterns or forms. It also manifests a deeper engagement of other faculties, which, although not in the forefront, determine some aspects of our aesthetic responses. Within this understanding of aesthetic sensibility, the experience of ugliness in nature will be valuable as such in so far as it will be a necessary component of our overall aesthetic outlook. Without it nature will not be as aesthetically and cognitively interesting as with it.

I have tried to briefly summarize some of the main positions that have considered the claim of Positive Aesthetics as well as some of the problems they seem to face. The connection between positive aesthetic value and preservation has been brought, I think, beyond the limits of what seems rational and empirically sensible. If one sides preservationist policies one does not need to deny nature can be ugly. We can try to show that ugliness may still have a place within a view that take our aesthetic relationship with nature as enough complex to be improved by the presence of negative aesthetic features. ${ }^{12}$

12. La reproducción de textos e imágenes en este artículo se acoge al texto refundido de la Ley de Propiedad Intelectual, en cuyo artículo 32 del Real Decreto Legislativo 1/1996, de 12 de abril (BOE número 97, de 22 de abril) con las modificaciones dadas al mismo por la Ley 5/1998 de 6 de marzo (BOE número 57, de 7 de marzo) y la Ley 1/2000 de 7 de enero (BOE número 7 de 8 de enero), se dice lo siguiente: «Es lícita la inclusión en una obra propia de fragmentos de otras obras ajenas de naturaleza escrita, sonora o audiovisual, así como la de obras aisladas de carácter plástico, fotográfico, figurativo o análogo, siempre que se trate de obras ya divulgadas y su inclusión se realice a título de cita o para su análisis, comentario o juicio crítico. Tal utilización sólo podrá realizarse con fines docentes o de investigación, en la medida justificada por el fin de esa incorporación e indicando la fuente y el nombre del autor de la obra utilizada». 